\title{
JEZZYOWO-KOMUNIKACYJNE CECHY POLECEŃ W WYBRANYCH MATERIAŁACH DYDAKTYCZNYCH DO NAUKI JEZYKA POLSKIEGO JAKO OBCEGO
}

\begin{abstract}
Słowa kluczowe: polecenie, polecenie służbowe, polecenie dydaktyczne, glottodydaktyka polonistyczna, pragmalingwistyka

Streszczenie. Za punkt wyjścia przyjmuje się w artykule postulaty badawcze zaprezentowane ponad 20 lat temu przez Annę Burzyńską (1998) w publikacji poświęconej poleceniom dydaktycznym. Rozwój językoznawstwa oraz zmiany w glottodydaktyce, jakie dokonały się w tym czasie, są ważnymi przesłankami, które uzasadniają podjęcie tej tematyki na nowo. W części pierwszej niniejszego artykułu, teoretyczno-deskrypcyjnej, polecenie zostało poddane eksplikacji pragmatycznej (jako akt mowy) i charakterystyce komunikacyjnej (w sytuacji urzędowej i w sytuacji dydaktycznej). W części drugiej przedstawiono wyniki analizy wybranych podręczników i zeszytów ćwiczeń do nauki języka polskiego jako obcego na poziomie podstawowym i średnio zaawansowanym pod kątem zawartych w nich poleceń. Obie części służą jako podstawa do sformułowania wniosków końcowych. Zasadnicza konkluzja, jaką formułuje się w artykule, brzmi: tzw. polecenia dydaktyczne w podręcznikach i zeszytach ćwiczeń są aktami mowy potencjalnymi, aktualizowanymi każdorazowo w konkretnej sytuacji dydaktycznej, a szablonowość i schematyzm nie są ich wadami, lecz cechami pożądanymi; dotyczą bowiem strony formalnej poleceń oraz nazw powtarzalnych czynności, które pomagają kształcić podstawowe umiejętności, oryginalne natomiast są (powinny być) obiekty owych czynności (zawartość ćwiczeń i zadań, teksty itp.).
\end{abstract}

\section{WPROWADZENIE}

Ponad 20 lat temu w czasopiśmie Acta Universitatis Lodziensis. Kształcenie Polonistyczne Cudzoziemców ukazał się artykuł Anny B. Burzyńskiej (1998) poświęcony poleceniom dydaktycznym w podręcznikach do nauczania języka polskiego jako obcego. Od tego czasu temat poleceń w opracowaniach z zakresu glottodydaktyki polonistycznej nie był właściwie w ogóle podejmowany. Po-

*ewa_smiech@wp.pl, Uniwersytet Łódzki, Wydział Filologiczny, Instytut Filologii Polskiej i Logopedii, Zakład Współczesnego Języka Polskiego, ul. Pomorska 171/173, 90-236 Łódź, ORCID: 0000-0002-3385-6898. 
nieważ jednak, po pierwsze, polecenia są niezwykle ważnym elementem w dydaktyce, po drugie, w ciągu 20 lat znacznie zmieniło się podejście do nauczania języków obcych: nauczanie gramatyczno-leksykalne zastąpiło nauczania nastawione na komunikację i pragmatykę (Seretny, Lipińska 2005, s. 15), po trzecie wreszcie, wzrosła znacząco liczba podręczników do nauczania języka polskiego jako obcego, konieczne wydaje się zbadanie, czy ustalenia i postulaty A. Burzyńskiej sprzed lat są nadal aktualne, czy można je odnieść do dzisiejszej praktyki glottodydaktycznej i czy zmiany w samym językoznawstwie, tj. nowe językoznawcze paradygmaty badawcze mogą przynieść inne niż prezentowe $\mathrm{w}$ pracy wrocławskiej badaczki spojrzenie na tak ważną w dydaktyce jednostkę, jaką jest polecenie.

Materiał do rozważań analitycznych pochodzi z następujących podręczników na poziomie średnio zaawansowanym i podstawowym:

a) Piotra Lewińskiego (2001) pt. Oto polska mowa [dalej skrót: L];

b) Agnieszki Madei i Barbary Morcinek (2007) pt. Polski mniej obcy, Poziom średnio ogólny (B2), cz. 1 [dalej: M/M];

c) Aleksandry Janowskiej i Magdaleny Pastuchowej (2009) pt. Dzień dobry!, Poziom podstawowy A1 [J/P];

d) Iwony Stempek, Pauliny Kuc, Małgorzaty Grudzień (2016) pt. Polski 1. Krok po kroku. Junior. Zeszyt ćwiczeń. Poziom 1 (A1) [S/K/G].

Dwa pierwsze podręczniki stanowią główną część materiałową, są to bowiem - podobnie jak poddane analizie przez A. Burzyńską - podręczniki na poziomie średnio zaawansowanym. Książka P. Lewińskiego jest jednym z pierwszych podręczników nastawionych na rozwijanie sprawności komunikacyjnych, z kolei podręcznik A. Madei i B. Morcinek reprezentuje publikacje opracowane pod kątem egzaminu certyfikatowego. Jako tło porównawcze zostały wybrane książki dla początkujących: podręcznik i zeszyt ćwiczeń. Publikacje te różni nie tylko czas powstania, miejsce wydania, ale i przeznaczenie, a mimo to mają bardzo wiele cech wspólnych i - jak się wydaje - interesujących z punktu widzenia podjętych tu rozważań.

\section{POLECENIE DYDAKTYCZNE W UJECCIU ANNY BURZYŃSKIEJ}

Opis poleceń dydaktycznych, jaki przedstawiła A. Burzyńska w swoim artykule, skupia się na kilku zagadnieniach: strukturze zdań dydaktycznych, strukturze i semantyce poleceń, ich schematyzmie i sposobach radzenia sobie lektorów z niespełniającymi ich oczekiwań poleceniami podręcznikowymi ${ }^{1}$. Najważniej-

${ }^{1}$ Zwrócić należy uwagę, że dopiero w 1991 roku pojawiła się książka Waldemara Martyniuka Mów do mnie jeszcze, uznawana za pierwszy na polskim rynku podręcznik komunikacyjny do nauki języka polskiego jako obcego. 
sze z punktu widzenia uwag zawartych $\mathrm{w}$ dalszych partiach niniejszego tekstu są formułowane przez A. Burzyńską postulaty badawcze, powstałe na podstawie przeprowadzonych przez autorkę obserwacji:

Podsumowując (...) rozważania nad efektywnością glottodydaktyczną poleceń w podręcznikach do nauki języka polskiego jako obcego na poziomie średnio zaawansowanym, chciałabym wskazać na znaczną dysproporcję, która wynika z porównania zamierzonych przez autorów funkcji (efektywność zamierzona) z ich rzeczywistą skutecznością w procesie nauczania języka polskiego (efektywność rzeczywista).

Aby uniknąć wspomnianej dysproporcji i osiągnąć pełną efektywność glottodydaktyczną, autorzy podręczników przy tworzeniu poleceń dydaktycznych powinni zwrócić uwagę na:

1) odpowiedni styl wypowiedzi dyrektywnych,

2) nieskomplikowaną strukturę syntaktyczną,

3) właściwe proporcje w stosowaniu terminologii gramatycznej,

4) precyzyjne formułowanie problemów,

5) oryginalność i atrakcyjność (nieschematyczność) (Burzyńska 1998, s. 11).

\section{POLECENIE JAKO AKT MOWY}

Polecenie jest aktem mowy dyrektywnym. Oznacza to, że nadawca aktu polecenia nakłania odbiorcę do podjęcia lub zaprzestania określonych działań. Samo nakłanianie łączy się już z kategorią władzy - faktyczną (np. jaką ma przełożony w pracy lub nauczyciel w szkole) lub symboliczną (jaką mają np. media czy reklama), a zatem implikuje nierównorzędny układ nadawczo-odbiorczy. W obrębie przekazów nakłaniających akty dyrektywne odróżnia od aktów perswazyjnych cel działań werbalnych podejmowanych przez nadawcę. O ile w przypadku aktów perswazyjnych nadawca nakłania odbiorcę do zmian o charakterze mentalnym (por. Grzegorczykowa 1991), zatem też częściej u ich podstaw leży symboliczna relacja władzy, o tyle akty dyrektywne, które - jak już zostało powiedziane - dotyczą podjęcia (zaprzestania) określonych działań, wynikają z relacji władzy instytucjonalnej, społecznie i najczęściej także prawnie usankcjonowanej. Oznacza to jednocześnie, że akt polecenia powstaje w sytuacji oficjalnej zależności, w układach zawodowych, w relacjach służbowej nadrzędności i - co bardzo ważne - jako taki ma zawsze określonego nadawcę (tj. wydającego polecenie) i określonego odbiorcę (tj. tego, kto polecenie ma wykonać). Nie chodzi jednak tylko o odbiorcę (nadawcę) indywidualnego, pojedynczego w sensie fizycznym. Odbiorca (nadawca) aktu polecenia może mieć charakter zbiorowy (grupowy), ale także wtedy jest to zbiorowość określona (np. zarząd lub dyrekcja danej instytucji jako nadawca czy pracownicy danego działu firmy lub uczniowie danej klasy jako odbiorca zbiorowy). 
Wśród aktów dyrektywnych polecenie w największym stopniu związane jest z takimi formami wypowiedzi jak prośba, zakaz i nakaz. Słowniki języka polskiego definiują te wymienionej wyżej leksemy w sposób następujący:

polecenie: SJP Dor «zlecenie, rozporządzenie, rozkaz»; SJP PWN «wypowiedź nakazująca komuś wykonanie jakiejś czynności»;

nakaz: SJP Dor «ustne lub pisemne wyrażenie czyjeś woli, której należy się podporządkować; rozporządzenie, rozkaz, polecenie» Nakaz kwaterunkowy. Nakaz pracy; SJP PWN «ustne lub pisemne polecenie, któremu należy się podporządkować» nakaz karny, nakaz kwaterunkowy;

zakaz: SJP Dor: «zarządzenie, rozkaz, polecenie zabraniające czego» Surowy zakaz. Przestrzegać zakazów. Łamać, przekraczać zakazy. Wydać, uchylić zakaz; SJP PWN «zarządzenie lub polecenie zabraniające czegoś»;

prośba: SJP Dor: 1.«skierowanie do kogoś jakiegoś życzenia i naleganie na jego spełnienie; proszenie» Gorąca, uniżona, natarczywa prośba. Milcząca, niema prośba. Mieć do kogoś prośbę, zwrócić się do kogoś z prośbą. Wysłuchać czyjejś prośby. Przychylić się do czyjeś prośby. Zrobić co na czyjąś prośbę. Uwzględnić czyjąś prośbę. 2.«życzenie wyrażone na piśmie; podanie, petycja» Wnieść prośbę. Przyjąć prośbę; SJP PWN 1. «uprzejme zwrócenie się do kogoś w celu uzyskania, wyjednania czegoś»; 2.«życzenie wyrażone na piśmie, skierowane do jakiejś instytucji lub osoby urzędowej».

Definicje słownikowe oraz ustabilizowane połączenia wyrazowe (nakaz: karny, kwaterunkowy; polecenie / nakaz zapłaty; polecenie: służbowe) wskazują na to, że: po pierwsze - wymiennie używa się określeń: polecenie i nakaz, po drugie - między nakazem a zakazem różnica zasadza się na negacji: nakaz = działanie (rób / zrób to), zakaz = niedziałanie (nie rób tego), po trzecie - różnica między polecenie, nakazem, zakazem a prośbą jest związana z różną siłą funkcji dyrektywnej aktów mowy nazwanych wymienionych wyrazami: prośba (życzenie) ma zdecydowanie słabszą w stosunku do polecenia, nakazu, zakazu (zarządzenia, zalecenia, rozporządzenia) moc dyrektywną, dopuszcza bowiem odmowę.

Anna Wierzbicka, stosując tzw. elementarne jednostki semantyczne, parafrazuje akt prośby w sposób następujący (Wierzbicka 1999, s. 23633): (a) mówię: chcę, żebyśs zrobit dla mnie coś dobrego (X), (b) mówię to, bo chcę, żebyś to zrobit, (c) myślę: nie musisz tego robić, (d) nie wiem, czy to zrobisz. Wzmocnienie funkcji dyrektywnej zmieni prośbę w nakaz': (a) mówię: chcę, żebyś zrobit X,

${ }^{2}$ Definicja zawarta w słowniku online jest definicją tautologiczną (por. znaczenie leksemu polecenie podane w SJP PWN: 'wypowiedź nakazująca komuś wykonanie jakiejś czynności’ i frazę z definicji leksemu nakaz: '(...) polecenie, któremu należy się podporządkować’). Tej usterki nie zawiera definicja w słowniku pod redakcją Doroszewskiego.

${ }^{3}$ A. Wierzbicka definiuje akt prośby w języku angielskim. Eksplikacja, jaką podaje autorka, ma jednak również zastosowanie do prośby w polszczyźnie.

${ }^{4}$ A. Wierzbicka (1999, s. 236) te cechy przypisuje rozkazowi. Uważam, że rozkaz i polecenie są tymi samymi aktami mowy, implikującymi stosunek hierarchiczny między nadawcą i odbiorcą. Różna może być tylko ich pragmatyczna dystrybucja: polecenie (nakaz, zakaz) łączy się z sytuacją 
(b) mówię to, bo chcę, żebyś to zrobit, (c) myślę: musisz to robić z tego powodu (tzn. bo chcę, żebyś to zrobit), (d) myślę, że zrobisz to z tego powodu.

Zanegowanie działania przekształci akt nakazu w zakaz; por. (a) mówię: chcę, żebyś nie (z)robit X; (b) mówię to, bo chcę, żebyś tego nie (z)robit itd. Na podstawie eksplikacji wszystkich trzech pokrewnych aktów mowy można opisać polecenie jako taki gatunek (genr), który łączy cechy nakazu i zakazu oraz przeciwstawia się prośbie ${ }^{5}$. Zatem polecenie jest aktem dyrektywnym obejmującym zarówno nakazy, jak i zakazy - na co oprócz znaczeń słownikowych wskazuje także polska praktyka nominacyjna, czyli typy poleceń wyodrębniane ze względu na ich pozytywną (tj. dotyczącą działania) lub negatywną ( $\mathrm{tj}$. dotyczącą niedziałania lub zaprzestania działania) treść (por. wykres 1).

Wykres 1. Polecenie jako akt dyrektywny

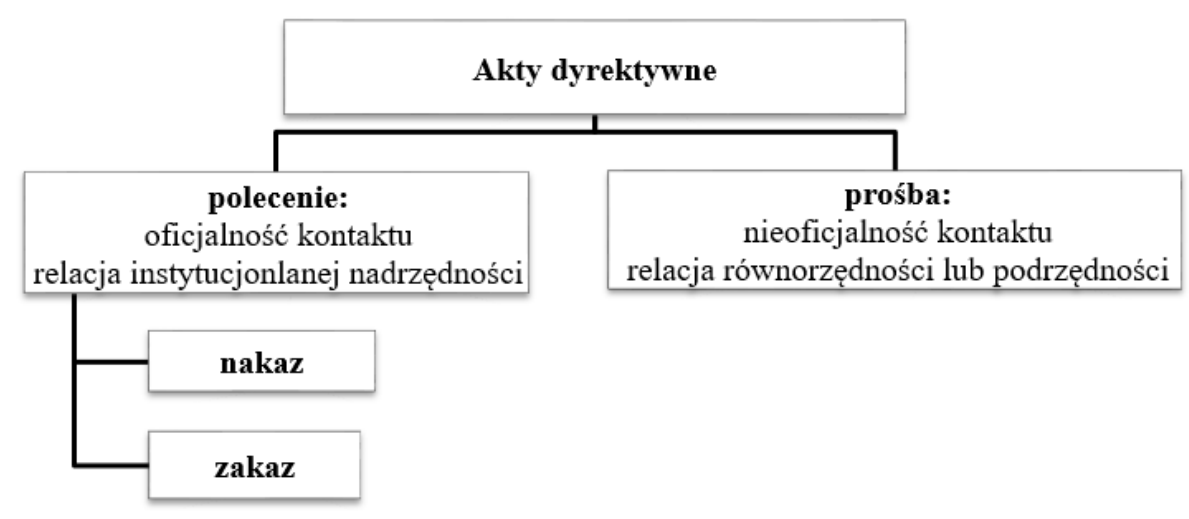

Źródło: opracowanie własne

\section{POLECENIE SLUŻBOWE A POLECENIE W DYDAKTYCE}

We współczesnej praktyce komunikacyjnej istnieją dwa zasadnicze typy poleceń: polecenie służbowe i polecenie dydaktyczne ${ }^{6}$.

urzędową, służbową, instytucjonalną w ogóle, rozkaz zaś jako szczególny typ polecenia (nakazu, zakazu) - głównie z sytuacją służbową w wojsku, policji, służbach specjalnych, w których sankcje za niewykonanie są znacznie surowsze niż gdzie indziej.

${ }^{5}$ To przeciwstawienie ma charakter pragmatyczny, nie formalny (o czym w dalszej części artykułu). I prośba, i polecenie mogą być wyrażane za pomocą tych samych środków językowych, por. Marcjanik 2017, s. 269: „Po możliwości odmówienia spełnienia prośby rozpoznaje się bliskie prośbom polecenia (nieraz podobne lub identyczne ze względu na formę językową). Jeżeli odmowa pociąga za sobą konsekwencje typu służbowego, świadczy to o tym, że nie jest ona odmową spłonienia prośby, lecz odmową wykonania polecenia".

${ }^{6} \mathrm{~W}$ stosunku do pisemnych urzędowych poleceń używa się innych nominacji, np. nakaz urzędowy, administracyjny; nakaz / polecenie zapłaty czy decyzja administracyjna (por. Malinowska 2001). 
Polecenie służbowe jest jednym z najważniejszych aktów mowy funkcjonujących w każdej instytucji, precyzyjnie więc definiuje się je w wielu tekstach administracyjno-urzędowych i określa jego najważniejsze, konstytutywne cechy (m.in. Polecenie stużbowe w orzecznictwie SN 2010; Polecenie stużbowe w administracji; Ustawa z 22 marca 1990; Ustawa z 16 września 1982; Kodeks pracy). Na ich podstawie można uznać, że:

- wykonywanie poleceń służbowych należy do podstawowych obowiązków każdego zatrudnionego,

- polecenie służbowe jako najważniejsza wewnętrzna forma działania instytucji jest wydawane na podstawie ogólnego upoważnienia zawartego w odpowiednich aktach prawnych w warunkach nadrzędności i podporządkowania służbowego,

- kształtuje sytuację prawną konkretnego podmiotu, ponieważ zobowiązuje go do czynienia (nakaz) bądź nieczynienia czegoś (zakaz), a sankcją za niewykonanie są środki dyscyplinarne,

- musi mieścić się w granicach prawa, tzn. może je wydawać tylko osoba prawnie upoważniona i tylko $\mathrm{w}$ granicach swoich kompetencji i w ramach obowiązków służbowych adresata,

- nie może być sprzeczne z prawem,

- zawiera dyrektywę skierowaną przez zwierzchnika służbowego do podległego mu pracownika, w której określa się sposób wykonania obowiązku ciążącego na adresacie tego polecenia.

Sądzę, że powyższe pragmatyczno-funkcjonalnej cechy polecenia służbowego da się przenieść - po dokonaniu pewnych modyfikacji - na grunt dydaktyki i tym samy wskazać podobieństwa między obu typami aktów, a cechy powtarzalne uznać za właściwości konstytutywne wszelkich typów poleceń. Analogicznie do cech polecenia służbowego można określić cechy polecenia dydaktycznego (w dydaktyce):

- wykonywanie poleceń dydaktycznych należy do podstawowych obowiązków ucznia,

- polecenie dydaktyczne jest jedną z najważniejszych form działania w sytuacji dydaktycznej, wydawaną na podstawie konwencjonalnego lub instytucjonalnego upoważnienia danego nauczycielowi w warunkach nadrzędności i podporządkowania, a sam akt dyrektywny i zawarta w nim nierównorzędność komunikacyjna jest legitymizowana społeczną lub instytucjonalną rolą nauczyciela,

- kształtuje sytuację dydaktyczną adresata polecenia (ucznia), ponieważ zobowiązuje go do wykonania zadania; sankcje są określone w procesie dydaktycznym (oceny, system nagród i kar), 
- musi być wydawane przez nauczyciela w granicach jego kompetencji zawodowych i możliwości ucznia określonych w odrębnych aktach (podstawa programowa, statut, regulamin) i nie może być sprzeczne z prawem,

- zawiera dyrektywę skierowaną przez nauczyciela do ucznia, w której określa się sposób wykonania zadania dydaktycznego.

Do cech konstytutywnych polecenia jako aktu mowy należy: instytucjonalna zależność nadawcy i odbiorcy aktu, obligacja spoczywająca na adresacie i sankcje za brak podporządkowania się, zgodność treści zadania z prawem i kompetencjami nadawcy, eksplicytność sposobu wykonania.

Z teoretycznych rozważań dotyczących pragmatycznych cech i komunikacyjnych zależności, w jakie uwikłane jest polecenie, wynika kilka bardzo ważnych wniosków dotyczących ,poleceń” zawartych w podręcznikach:

a) tzw. polecenia dydaktyczne w podręcznikach są potencjalnymi aktami mowy, są potencjalnymi poleceniami dydaktycznymi;

b) potencjalności aktów poleceń w podręcznikach oznacza jednocześnie ich umowność jako aktów mowy;

c) aktualizacja następuje dopiero w praktyce dydaktycznej opartej na relacji: nauczyciel - uczeń, a więc polecenia podręcznikowe aktualizują się w sytuacji dydaktycznej ${ }^{7}$.

\section{POLECENIA DYDAKTYCZNE W PODRECZNIKACH}

W materiałach dydaktycznych do nauki języka polskiego jako obcego występują dwa podstawowe typy poleceń: wyrażane w sposób bezpośredni (a więc jako bezpośrednie akty mowy) i wyrażane w sposób pośredni (a więc jako pośrednie akty mowy). Funkcja dyrektywna aktu mowy jest wyrażona eksplicytnie za pośrednictwem imperatywnych form czasownika, np. prosze przeczytać, prze$c z y t a j{ }^{8}$. Autorzy podręczników wybierają jedną z dwu możliwych form i stosują w książce niemal bez wyjątku tylko jedną, por. np.[L] - forma 2. os. 1. poj. (rzadko 1. mn.) trybu rozkazującego czasownika (przeczytaj, napisz); [S/K/G], [J/P],

\footnotetext{
${ }^{7}$ Por. brak aktualizacji poleceń w procesie samodzielnej nauki.

${ }^{8}$ Inne możliwe formy gramatyczne w podobnej (impresywnej) funkcji to np.: Przeczytaj, proszę...; Czy mógłbyś / mogłabyś / mógłby Pan / mogłaby Pani / mogliby Państwo przeczytać...; Czy byłbyś / byłby Pan laskaw przeczytać... Ich wystąpienie jest zależne od typu interakcji, wieku uczestników itp. Mimo że formy te mogą funkcjonować także w akcie prośby, w sytuacji dydaktycznej są poleceniem, por. Monika i Marek postanowili podczas wakacji zwiedzić kilka pięknych miejsc. Ponieważ mieli mało pieniędzy, podróżowali różnymi środkami lokomocji. Czy możesz na podstawie obrazków uzupetnić ich relację z podróży? [L]; Jeśli możesz, przynieś na lekcję zdjęcia i opowiedz wszystkim o swoich podróżach [L]. Oba przykłady, jeśli zostaną zaktualizowane w sytuacji dydaktycznej, spełnią funkcję poleceń.
} 
$[\mathrm{M} / \mathrm{M}]$ - forma bezokolicznika z czasownikiem grzecznościowym proszę (proszę przeczytać, proszę napisać) $)^{9}$.

Pośrednie akty polecenia, w których funkcja dyrektywna jest implicytna, przybierają postać pytania dydaktycznego, np. Jaka jest kuchnia twojego kraju? [L] (= Odpowiedz na pytanie: Jaka jest (...)?); Co trzeba zrobić, żeby przygotować wymienione potrawy? [L] (= Odpowiedz na pytanie: Co trzeba zrobić (...)?). Drugim typem pośrednich poleceń dydaktycznych jest określenie sposobu wykonania zadania, tj. podanie samej instrukcji wykonania zadania za pomocą exemplum, np. Wojtek: „Jutro idę do kina z przyjacielem” / Wojtek mówi, że jutro idzie do kina z przyjacielem $[\mathrm{J} / \mathrm{P}]$ (=Proszę przeksztatcić podane zdania $w$ taki sposób [lub: z mowy niezależnej na mowę zależna], jak w przykładzie pierwszym: Wojtek: „Jutro (...) / Wojtek mówi, że (...)).

Polecenie dydaktyczne zbudowane jest $\mathrm{z}$ dwu jednostek semantycznych (por. Burzyńska 1998, s. 6-7). Jedną, obligatoryjną, stanowi czasownik wyrażający czynność (A), jaką należy wykonać, drugą - fakultatywną - obiekt czynności (B), na którym dana czynność ma zostać wykonana, np.:

- (A:) Proszę wpisać (B:) odpowiednie wyrazy [J/P, 5]; (A:) Proszę połaczyć [J/P, 21];

- (A:) Proszęuzupetnić (B:) stowami z tabelki [S/K/G, 31]; (A:) Proszę uzupetnić [S/K/G, 30]; (A:) Proszę postuchać i uzupetnić (S/K/G, 29];

- (A1:) Opisz (B1:) swoje własne mieszkanie i (A2:) opowiedz [koleżankom i kolegom], (B2:) jakie wnętrza lubisz najbardziej [L, 68];

- (A1:) Proszę przyjrzeć się (B1:) formom skargi i reklamacji, a następnie (A2:) wskazać (B2:) podobieństwa i różnice w ich budowie [M/M, 56].

Współczesne podręczniki do nauczania języków obcych mają na celu kształcenie umiejętności komunikacyjnych, które sprowadzają się do czterech podstawowych działań językowych:

a) związanych z tworzeniem tekstów, tj. - pisania (tworzenia tekstu pisanego), - i mówienia (tworzenia tekstu mówionego) oraz

${ }^{9}$ A. Wierzbicka (1999, s. 204) wskazuje na bardzo ważną pragmatyczną cechę poleceń bezokolicznikowych: „Gdy mówiący chce wyrażać się uprzejmie, a zarazem pragnie niezależnie od tego sygnalizować chłód i brak poufałości, bezokolicznik może być użyty w połączeniu z czasownikiem performatywnym: (...) Proszę powiedzieć, proszę się nie krępować (...). W pewnym sensie polecenie $\mathrm{w}$ formie bezokolicznikowej funkcjonuje w polszczyźnie jako środek ustanawiania dystansu, podobnie jak to się dzieje w języku angielskim z poleceniem w formie pytajnej. Ale w kulturze anglosaskiej dystans jest wartością kulturowo pozytywną, ponieważ łączy się z respektowaniem autonomii jednostki. Przeciwnie jest w kulturze polskiej, gdzie łączy się on z wrogością i wyobcowaniem". Z kolei A. Burzyńska (1998) uznaje polecenia dydaktyczne bezokolicznikowe za formę grzeczniejszą niż rozkaźnik 2. osoby: „(..) w analizowanych poleceniach (...) dominuje forma trybu rozkazującego 2 os. 1. poj., np. wymień, zobacz, zwróć uwagę, uzupetnij lub częściej - forma opisowa, bardziej grzeczna, np. Proszę odpowiedzieć, proszę przeczytać". Wbrew pozorom obie opinie nie są sprzeczne. W sytuacji dydaktycznej dystans jest cechą pożądaną, a instytucjonalny charakter interakcji znosi ewentualne wrażenie wrogości czy obcości. 
b) związanych z odbiorem tekstów, tj.

- czytania (rozumienia tekstu pisanego),

- i słuchania (rozumienia tekstu mówionego).

Te cele są bardzo wyraźnie odzwierciedlone w semantyce poleceń, w ich części nazywającej czynność, jaką uczeń ma wykonać. W dwu analizowanych podręcznikach na poziomie średnio zaawansowanym łącznie wystąpiło:

- [L] ok. 240 poleceń eksplicytnych, w tym ok. 50 różnych nazw czynności (czasowników),

- [M/M] ok. 340 poleceń eksplicytnych, w tym ok. 80 różnych czasowników.

Dane te pokazują ogromne bogactwo leksykalne stosowane przez autorów do nazwania podstawowych czynności, jakie stanowią zadanie dydaktyczne. Poniższa tabela (1) zawiera te czasowniki, które pojawiły się w poleceniach co najmniej 5 razy. Bardzo wyraźnie widać zgodność zadań określonych za pomocą czasowników z podstawowymi celami podręczników. Książka A. Madei i B. Morcinek Polski mniej obcy... jest podręcznikiem dostosowanym do wymagań certyfikacji na poziomie B2. Najliczniej reprezentowane są w poleceniach czasowniki: powiedzieć (35 razy), przeczytać (34), wystuchać (28), napisać (26), a więc odpowiadające czterem częściom egzaminu: mówienie, czytanie, słuchanie, pisanie. Z kolei podręcznik P. Lewińskiego to jeden z pierwszych podręczników nastawionych na kształcenie komunikacyjne. Wydany został w 2001 roku, więc nie dziwi brak materiałów audialnych czy audiowizualnych, tym samym brak poleceń dotyczących słuchania. Dominują zatem czasowniki dotyczące pisania: uzupetnij (28 razy), czytania: przeczytaj (17), mówienia: opowiedz (12), powiedz (12), porozmawiaj (11), z wyraźną przewagą poleceń nastawionych na mówienie, por.:

Tabela 1. Lista frekwencyjna czasowników występujących w poleceniach eksplicytnych

\begin{tabular}{|c|c|}
\hline [M/M] Polski mniej obcy & [L] Oto polska mowa \\
\hline - 35: (proszę) odpowiedzieć (na pytanie) & - 28: uzupełnij \\
\hline - 34: (proszę) przeczytać & - 18: spróbuj: dowiedzieć się, odpowiedzieć, \\
\hline - 28: (proszę) wysłuchać (nagrania, tekstu) & odgadnąć, połączyć, poprawić, ułożyć, \\
\hline - 26: (proszę) napisać & uogólnić, ustalić (kolejność, znaczenie), \\
\hline - 19: (proszę) uzupełnić & wyjaśnić (znaczenie), zachęcić, znaleźć, \\
\hline - 9: (proszę) opowiedzieć & zrozumieć, ustalić \\
\hline - 8: (proszę) wpisać & - 17: przeczytaj \\
\hline - 7: (proszę:) dobrać; wypisać; & - 12: opowiedz / powiedz \\
\hline zastanowić się & - 11: porozmawiaj $(\mathrm{z})$ \\
\hline - 6: (proszę:) opisać; spróbować & - 10: skorzystaj (ze słownika, z wyrazów) \\
\hline (opowiedzieć: 2, przygotować, $\mathrm{l}$ & - 9: odpowiedz (na pytanie) \\
\hline wypisać, zaśpiewać); wstawić; wybrać & - 8: połącz \\
\hline
\end{tabular}




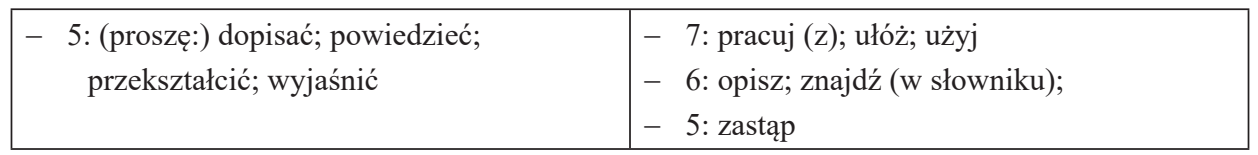

Źródło: opracowanie własne ${ }^{10}$

Zawarte w poleceniach czasowniki, powtarzane wielokrotnie, są przyswajane mimochodem. Niejako przy okazji nabywania innych sprawności wzbogacają zasób leksykalny uczących się języka o kolejne jednostki bliskoznaczne, konstrukcje analityczne, peryfrazy, a także kształcą bardzo ważną i niezwykle trudną do opanowania umiejętności właściwego posługiwania się czasownikami prefiksalnym, por. np.:

a) czasowniki bliskoznaczne dotyczące mówienie występujące w poleceniach w dwu podręcznikach (M/M i L): opowiedzieć; powiedzieć; porozmawiać; przeprowadź rozmowę; wyjaśnić; wypowiedzieć się; wyrazić opinię; zaprezentować; zreferować; zrelacjonować;

b) konstrukcje analityczne, peryfrazy: nadać tytut (=zatytułować); podać nazwę (=nazwać); podać uzasadnienie (=uzasadnić); postawić diagnozę

${ }^{10}$ Czasowniki występujące we wszystkich poleceniach w obu podręcznikach mniej niż 5 razy można zebrać w trzy grupy semantyczne. Są to:

a) czasowniki związane z tworzeniem tekstów (mówionych lub pisanych)

- M/M: [proszę] dokończyć (opowiadanie, zdanie), nadać (tytut), nazwać, określić, opracować, podać nazwy, podsumować, przedstawić, przeksztatcić, przytoczyć, scharakteryzować, streścić, ujać (treść), ułożyć, użyć, wskazać (podobieństwa, różnice), zastapić, zastosować, zbudować wypowiedź;

- L: dokończ, doradź, nazwij, objaśnij, określ, podaj (przepis, uzasadnienie, przyczyny), porównaj I porównajcie, postaw diagnozę, przedstaw (wady i zalety), przekształć, przeprowadź (ankiete), przygotuj (oferte), spróbuj utożyć, spróbuj uogólnić (wnioski), spróbuj wyjaśnić (znaczenie), spróbuj zachęcić, ułóż (zdania) / ułóżcie, użyj / nie używaj, wyjaśnij;

b) czasowniki w zadaniach mentalnych i przygotowawczych (mówienie, pisanie, czytanie, słuchanie następuje później):

- M/M: [proszę] dobrać, dopasować, dowiedzieć się, obejrzeć, pamiętać, pogrupować, połaczyć, przygotować (co? z kim?), przygotować się (do przedstawienia), przyjrzeć się, przyporzadkować, skorzystać (z), sprawdzić, spróbować przygotować, spróbować ustalić, stworzyć, uporzadkować, ustalić, utworzyć, wybrać, wymyślić, wyszukać, zapoznać się (z), zastanowić się, zdecydować, zebrać argumenty, zwrócić uwagę;

- L: dopasuj, dowiedz się, odgadnij, pamiętaj, podziel (przymiotniki, na grupy), połacz, przyjrzyj się I przyjrzyjcie się, przypomnij sobie, spójrz (na rysunek, obrazek, zdjęcie), spróbuj połaczyć , spróbuj ustalić (kolejność, znaczenie), spróbuj znaleźć (rozwiąanie, sposób leczenia), spróbuj zrozumieć (sens), spróbuj dowiedzieć się, uporzadkuj, wybierz, wyobraź sobie / wyobraźcie sobie, zaplanuj, zastanów się;

c) czasowniki dotyczące innych sprawności (rysowanie, granie, śpiewanie, sprawdzanie w słownikach):

- M/M: [proszę] narysować, podzielić się (na role), spróbować zaśpiewać, uwzględnić (rekwizyty), wcielić się $w$ rolę;

- L: skorzystaj (ze stownika, z wyrazów), pracuj (z koleżanka / kolegą; w grupie), znajdź (w stowniku). 
(=zdiagnozować); przeprowadzić dyskusję (=przedyskutować); wcielić się $w$ rolę (=zagrać); wyrazić opinię, zbudować wypowiedź (=wypowiedzieć się); sporządzić charakterystykę (=scharakteryzować);

c) prefiksalne derywaty czasownikowe (na przykładzie czasownika pisać): dopisać; napisać; opisać; wpisać; wypisać; zapisać11.

Złożoność formalna poleceń jest - jak pokazują wybrane do analizy podręczniki - bardzo precyzyjnie dostosowana do możliwości percepcyjnych uczących się. Na poziomie podstawowym są to proste konstrukcje składniowe, na poziomie średnio zaawansowanym - znacznie bardziej złożone (por. przytoczone wcześniej przykłady).

Szczegółowa analiza zeszytu ćwiczeń dla młodzieży rozpoczynającej naukę języka polskiego (Polski 1. Krok po kroku. Junior) potwierdza jednak, że i tu mimo prostych konstrukcji składniowych, nierzadko ograniczonych tylko do orzeczenia (lub orzeczeń), np.: Proszę uzupetnić; Proszę skorygować; Prosze uporzadkować; Prosze dopasować; Prosze postuchać i ponumerować, lub zdań pojedynczych zawierających jedynie orzeczenie i dopełnienie, por. Proszę uzupetnić krzyżówkę / dialogi / komiks; Prosze skorygować tekst / litery; Proszę napisać dialog, polecenia zawierają bogatą leksykę związaną z kształconymi umiejętnościami: w ćwiczeniach wystąpiło ok. 200 poleceń eksplicytnych, w tym ok. 30 różnych nazw czynności (czasowników): uzupetnić (96 razy), postuchać (61), napisać (40), skontrolować (16), ułożyć, uporzadkować (po 9), skorygować (7), odpowiedzieć, uporzadkować, zaznaczyć (po 6), połaczyć, rozwiąać, zakreślić (4), powtórzyć, wybrać, zanotować (3), dokończyć, podpisać, pogrupować, pokolorować, ponumerować (2), dodać, narysować, opisać, przeczytać, przedyskutować, sprawdzić, zaprezentować (1) ${ }^{12}$. Czasowniki o największej frekwencji: uzupetnić, postuchać, napisać, bardzo jasno określają cel publikacji i umiejętności, które będą kształcone.

\section{PODSUMOWANIE}

Eksplicytna dyrektywność polecenia dydaktycznego przybiera dwie formy: 2. osoby trybu rozkazującego czasownika lub formy bezokolicznika poprzedzonego grzecznościowym proszę. To ograniczenie jest już pierwszym powodem schematyczności poleceń dydaktycznych stosowanych w podręcznikach. Ale ten schematyzm formalny służy jednocześnie precyzji i jednoznaczności, które po-

${ }^{11}$ Uczeń, wykonując polecenie, wykonuje także tę czynność: dopisuje, opisuje, wypisuje, a więc poznaje różnice semantyczne między czasownikami poprzez działanie.

${ }^{12}$ Dane liczbowe się nie sumują, ponieważ najczęściej polecenia mają charakter złożony, zwykle o postaci: (proszę) uzupetnić, postuchać, skontrolować / skorygować. 
winny być cechą obligatoryjną poleceń, pełnią bowiem one w pierwszej kolejności funkcję instrukcji wykonania zadania. Powtarzalność czynności, jakie wykonuje uczeń, by nabrać biegłości komunikacyjnej, ma także swoje odzwierciedlenie w powtarzalności czasowników i zasadniczych sensów poleceń dotyczących tego, co zrobić. Zatem nie należy w schematyzmie i powtórzeniach upatrywać wad poleceń stosowanych w materiałach dydaktycznych. Na wczesnym poziomie edukacji są to cechy wręcz pożądane. Każdorazowo jednak polecenia podręcznikowe, owe podstawowe instrukcje wykonania zadania, są aktualizowane w procesie dydaktycznym, w konkretnej sytuacji dydaktycznej i jako akty mowy funkcjonują dopiero wtedy, kiedy mają swojego konkretnego nadawcę (nauczyciela) i konkretnego odbiorcę (ucznia). Oryginalność i atrakcyjność zaś nie dotyczy kształconych umiejętności (mówienia, czytania, pisania, mówienia), a więc nie tego, co uczeń robi, ale tego, jaki jest „obiekt czynności” mówienia, czytania, pisania, słuchania.

\section{WYKAZ ANALIZOWANYCH PODRĘCZNIKÓW ORAZ SKRÓTÓW}

L: P. Lewiński: Oto polska mowa, Wrocław 2001.

M/M: A. Madeja, B. Morcinek, Polski mniej obcy, Poziom średnio ogólny (B2), cz. 1, Katowice 2007.

S/K/G: I. Stempek, P. Kuc, M. Grudzień, Polski 1. Krok po kroku. Junior. Zeszyt ćwiczeń. Poziom 1 (A1), Kraków 2016.

J/P: A. Janowska, M. Pastuchowa, Dzień dobry!, Poziom podstawowy A1, Tarnów 2009.

\section{BIBLIOGRAFIA}

Burzyńska A. B., 1998, Polecenia dydaktyczne w podręcznikach do nauczania języka polskiego jako obcego na poziomie średnim, „Acta Universitatis Lodziensis. Kształcenie Polonistyczne Cudzoziemców”, t. 10, B. Ostromęcka-Frączak (red.), s. 5-12.

Grzegorczykowa R., 1991, Problem funkcji języka i tekstu w świetle teorii aktów mowy, „Język a kultura", t. 2., J. Bartmiński, R. Grzegorczykowa (red.), Wrocław, s. 11-28.

Kodeks pracy, online: http://prawo.sejm.gov.pl/isap.nsf/download.xsp/WDU19740240141/U/ D19740141Lj.pdf [15.06.2018].

Malinowska E., 2001, Wypowiedzi administracyjne - struktura i pragmatyka, Opole.

Marcjanik M., 2017, Stownik językowego savoir-vivre'u, Warszawa.

Martyniuk W., 1991, Mów do mnie jeszcze, Kraków.

Polecenie stużbowe $w$ administracji, online: http://samorzad.infor.pl/sektor/organizacja/pracownicy/670873,Polecenie-sluzbowe-w-administracji.html [15.06.2018].

Polecenie stużbowe w orzecznictwie SN, 2010, online: www.prawo.egospodarka.p1/52050,Polecenie -sluzbowe-w-orzecznictwie-SN,1,34,3.html [15.06.2018].

Seretny A., Lipińska E., 2005, ABC nauczania metodyki języka polskiego jako obcego, Kraków.

SJP Dor.: Stownik języka polskiego, red. W. Doroszewski, https://sjp.pwn.pl/doroszewski/lista [22.10.2018]. 
SJP PWN, Stownik języka polskiego PWN, https://sjp.pwn.pl/ [22.10.2018].

Ustawa z 16 września 1982 r. o pracownikach urzędów państwowych, w: Dz.U. z 1982 r., nr 31, poz. 214.

Ustawa z 22 marca 1990 r. o pracownikach samorzadowych, w: Dz.U. z 2001 r., nr 142, poz. 1593.

Wierzbicka A., 1999, Język-umyst - kultura, Warszawa.

\section{Ewa Szkudlarek-Śmiechowicz}

\section{LINGUISTIC AND COMMUNICATIVE FEATURES OF INSTRUCTIONS IN SELECTED DIDACTIC MATERIALS FOR LEARNING POLISH AS A FOREIGN LANGUAGE}

Keywords: instruction, official instruction, didactic instruction, teaching Polish as foreign language, pragmalinguistics

Summary. The starting point for this article are postulates presented more than 20 years ago by Anna Burzyńska (1998) in a publication devoted to didactic instruction. The development of linguistics and changes in glottodidactics that have taken place since that time justify the resumption of such research. In the first part of the article, theoretical and descriptive, the genre of instruction is described from the point of view of pragmalinguistics (as a speech act) and its communicative features (in an official and didactic situation). The second part presents the results of the analysis of instructions found in selected textbooks and exercise books for learning Polish as a foreign language at the elementary and intermediate level. Both parts form the foundation for formulating the final conclusions. The main conclusion formulated in the article is that didactic instructions in textbooks and exercise books are potential speech acts, implemented each time in a particular didactic situation, and their schematism is not a disadvantage, but a desirable feature; this applies to the formal features of instructions and names of activities that help in teaching basic language skills, while the objects of these activities (texts, content of exercise and tasks, etc.) are (should be) novel. 